\title{
Endometrial progesterone receptor expression during the human menstrual cycle
}

\author{
S. Ingamells, I. G. Campbell, F. W. Anthony and E. J. Thomas* \\ Department of Obstetrics and Gynaecology, University of Southampton, Princess Anne Hospital, \\ Southampton SO16 5 YA
}

\begin{abstract}
The human endometrium undergoes regular cyclical changes under the endocrine control of oestrogens and progesterone acting via specific nuclear receptors. The molecular and cellular events mediating these changes are not understood. The present study examined the changes in the endometrial progesterone receptor and its mRNA during the menstrual cycle. Forty-four endometrial samples obtained from women with normal menstrual cycles were divided into four categories: early proliferative (days 6-9), late proliferative (days 10-14), early secretory (days 15-21) and late secretory (days 22-28). The progesterone receptor protein was determined using a human progesterone receptor enzyme-linked immunoassay kit. Total RNA was extracted using RNAzol and the abundance of mRNA encoding the progesterone receptor was determined by reverse transcriptase-polymerase chain reaction and by northern blot analysis. The concentration of the progesterone receptor in the endometrium was highest during the late proliferative phase and was lowest in the late secretory phase. Significant differences were observed between the menstrual cycle phases $(P<0.003)$. No cyclical variation was observed in the concentration of mRNA encoding for the progesterone receptor in the endometrium when analysed by reverse transcriptase polymerase chain reaction or by northern analysis. There appears to be no association between the amounts of mRNA encoding the progesterone receptor and progesterone receptor protein during the menstrual cycle suggesting that the control of the expression of the progesterone receptor may not occur solely at the transcriptional level.
\end{abstract}

\section{Introduction}

During the menstrual cycle, the endometrium undergoes regular cyclical changes so as to offer a suitable environment for the implantation of the fertilized ovum. These changes are under the influence of oestrogen and progesterone. Oestrogens induce endometrial proliferation during the preovulatory phase of the menstrual cycle (Ferenczy et al., 1979), whereas progesterone induces secretory changes in the oestrogen-primed proliferative endometrium during the post-ovulatory phase (Katzenellenbogen, 1980). The actions of progesterone and oestradiol are mediated by specific intracellular receptor proteins located in stromal and epithelial endometrial cells (Healy and Hodgen, 1983). Concentrations of progesterone receptors have been shown to be increased by oestrogen (Kreitmann et al., 1979) and growth factors (Sumida et al., 1988), and decreased by progesterone and progesterone analogues (Katzenellenbogen, 1980).

Regulation of the synthesis of progesterone receptors in breast cancer cells occurs at transcription (Read et al., 1988). In the endometrium, the concentration of progesterone receptors has been shown to vary throughout the menstrual cycle,

${ }^{*}$ Correspondence and requests for reprints.

Received 9 June 1995. although the mechanism by which this is achieved has not been established (Bayard et al, 1978). In the present investigation the relationship between mRNA encoding endometrial progesterone receptors and the progesterone receptor protein was studied throughout the menstrual cycle.

\section{Materials and Methods}

\section{Tissue samples}

Endometrial samples were collected from 44 women, age $36.8 \pm 6.2$ years (mean $\pm \mathrm{SD}$ ) with normal regular menstrual cycles undergoing routine gynaecology surgery. Women who had received hormonal treatment in the preceding six months were excluded from the study. Ethical approval for the study was obtained from the Local Ethics Committee and informed consent was obtained from each woman involved. Two samples were collected from each woman using a pipelle curette (Eurosurgical, Cranleigh). These samples were frozen immediately by immersion in liquid nitrogen and were stored for up to four months before mRNA encoding progesterone receptors was extracted and receptor assays performed. A third sample of endometrium was obtained by curettage. This sample was fixed in $4 \%(\mathrm{v} / \mathrm{v})$ formalin and stained with haematoxylin and eosin for histopathological evaluation. A peripheral blood sample 
was collected from each woman at the time of surgery for determination of the endocrine profile in the serum. Serum samples were stored in duplicate aliquots at $-20^{\circ} \mathrm{C}$ until assayed for progesterone and oestradiol.

Menstrual cycles were dated by last menstrual period and menstrual history. The dating of the menstrual cycle phase was confirmed by the histology (Noyes et al., 1950) and the serum profiles of progesterone and oestradiol (Yussman et al., 1970). The menstrual cycle was divided into four phases and the samples were allocated according to the phase of the cycle: early proliferative (EP) days 6-9 $(n=10)$; late proliferative (LP) days 10-14 $(n=11)$; early secretory (ES) days 15-21 $(n=15)$ and late secretory (LS) days 22-28 $(n=8)$.

Two breast cancer cell lines, MCF-7 and T47D, which express the progesterone receptor in large quantities (Horwitz ef al., 1978) were used as positive controls. The cells were grown in $150 \mathrm{~cm}^{2}$ flasks containing a growth medium of DMF1 containing Phenol red (Gibco, Paisley, Strathclyde) supplemented with $5 \mu \mathrm{g}$ amphotericin B, $50 \mu \mathrm{g}$ gentamycin $\mathrm{ml}^{-1}$ (Gibco) and 100 iu penicillin $\mathrm{ml}^{-1}$ (Northumbria Biologicals Ltd, Cramlington, Northumberland). The flasks were incubated at $37^{\circ} \mathrm{C}$ in an humidified atmosphere of $5 \% \mathrm{CO}_{2}$ in air. mRNA was prepared from the cells using a commercial mRNA isolation kit according to the manufacturer's instructions (Invitrogen, Abingdon, Oxon).

\section{Hormone assays}

The serum concentrations of progesterone (Kodak Clinical Diagnostics, Amersham, Bucks) and oestradiol (Serono Diagnostics, Fleet, Hants) were determined in duplicate using established radioimmunoassay kits. The minimum detectable serum concentrations were $0.25 \mathrm{nmol} \mathrm{l}^{-1}$ for progesterone and 18 pmol $1^{-1}$ for oestradiol. The interassay coefficients of variation were $8.6 \%$ and $6.4 \%$ for progesterone and oestradiol, respectively.

\section{Progesterone receptor assay}

A solid-phase enzyme immunoassay kit obtained from Abbott Laboratories (Chicago, IL) was used to determine the concentration of endometrial progesterone receptors. Cytosolic fractions of endometrium were prepared from $100 \mathrm{mg}$ of frozen tissue according to the assay manufacturer's instructions. The protein concentration in the cytosolic fractions was standardized to $1 \mathrm{mg} \mathrm{ml}^{-1}$ using a protein assay (Bio-Rad. Hemel Hempstead, Herts) based on the Coomassie brilliant blue method (Bradford, 1976). Receptor concentrations were determined from standard curves with an assay sensitivity of $5 \mathrm{fmol} \mathrm{ml} \mathrm{ml}^{-1}$. The control samples fell within the range specified by the manufacturer of the assay.

\section{Preparation of RNA}

Total RNA was extracted from $100 \mathrm{mg}$ of endometrium by homogenizing with RNAzol according to the manufacturer's recommended protocol (Biogenesis Ltd, Bournemouth, Hants). Routine protocols were followed to avoid RNase contamination of glassware and chemicals.
Semi-quantitative reverse transcription - polymerase chain reaction (RT-PCR)

Any contaminating DNA was removed from the endometrial RNA extracts by incubating 1 unit of RQI RNase-Free DNase (Promega, Southampton) with $10 \mu \mathrm{g}$ total RNA in $50 \mu \mathrm{l}$ buffer containing $40 \mathrm{mmol}$ Tris- $\mathrm{HCl} \mathrm{l}^{-1}, 6 \mathrm{mmol} \mathrm{MgCl}_{2} \mathrm{l}^{-1}$, $10 \mathrm{mmol} \mathrm{NaCl} \mathrm{l}^{-1}$ and $10 \mathrm{mmol}$ dithiothreitol $\mathrm{l}^{-1}$ for $15 \mathrm{~min}$ at $37^{\circ} \mathrm{C}$. The RNA was subsequently purified by one extraction in an equal volume of phenol and chloroform followed by one extraction in an equal volume of chloroform. The RNA was precipitated using $250 \mu \mathrm{l}$ ethanol, $10 \mu \mathrm{l}$ glycogen carrier (Invitrogen) and $200 \mathrm{mmol}$ sodium acetate $\mathrm{I}^{-1}$ and resuspended in nuclease-free water.

First strand cDNA was prepared from this material using a first strand synthesis kit (200420: Stratagene, CA) and an oligo $\mathrm{dT}$ primer (100 ng $\mu^{-1}$ ) (Promega, Southampton). RT-PCR was carried out on the endometrial CDNA in the presence of $0.25 \mathrm{mmol}_{\mathrm{dNTPs}} \mathrm{l}^{-1}$ (Promega), $50 \mathrm{ng}$ primers $\mu \mathrm{l}^{-1}, 0.2 \mu \mathrm{l}$ Taq polymerase (Promega), $1 \mu \mathrm{Ci}\left[\alpha_{-}{ }^{32} \mathrm{P}\right] \mathrm{dCTP}$ (Amersham International, Amersham, Bucks) and $1.5 \mathrm{mmol} \mathrm{MgCl}_{2} \mathrm{I}^{-1}$. An initial denaturing cycle of $94^{\circ} \mathrm{C}$ for 5 min was followed by 20-35 cycles under the following conditions: (1) primer annealing: $55^{\circ} \mathrm{C}$ for $30 \mathrm{~s}$, (2) primer extension: $72^{\circ} \mathrm{C}$ for $1 \mathrm{~min},(3)$ thermal denaturation: $94^{\circ} \mathrm{C}$ for $30 \mathrm{~s}$. Finally, a primer annealing cycle at $55^{\circ} \mathrm{C}$ for $30 \mathrm{~s}$ was followed by a $10 \mathrm{~min}$ primer extension cycle at $72^{\circ} \mathrm{C}$.

The sequences of the primers used for the progesterone receptor cDNA (Misrahi et al., 1987) and $\beta$-actin cDNA (Ponte et al., 1984) amplification were derived from the published cDNA sequences. $\beta$-Actin was used as an invariant control sequence in the PCR reactions to correct for reaction-toreaction variation in amplification efficiency. The primer sequences, the codons amplified and the expected sizes of the PCR product generated from the progesterone receptor cDNA are listed in Table 1 . The $\left[\alpha^{32} \mathrm{P}\right] \mathrm{dCTP}$-labelled PCR products obtained were separated on agarose gels and the bands visualized by staining the gel with ethidium bromide and viewing under ultraviolet light. The relevant bands were cut from the gel and the amount of radioactivity in each sample was measured in a beta counter. The ratio of the counts in the progesterone receptor product to the $\beta$-actin product was then determined.

\section{Northern analysis}

Endometrial RNA was analysed on northern blots using $\left[\alpha-{ }^{32} \mathrm{P}\right] \mathrm{dCTP}-\mathrm{labelled} \mathrm{DNA}$ probes for progesterone receptor and $\beta$-actin to determine the relative quantities of RNA present. Total RNA was denatured using $12.5 \mu$ formamide, $2.5 \mu \mathrm{l} \times 10$ Mops buffer and $4 \mu \mathrm{l} 37 \%(\mathrm{v} / \mathrm{v})$ formaldehyde and heating at $65^{\circ} \mathrm{C}$ for $5 \mathrm{~min}$. The solution was rapidly chilled on ice and mixed with $2.5 \mu \mathrm{l} 50 \%$ glycerol containing $0.1 \mathrm{mg}$ bromophenol blue $\mathrm{ml}^{-1}$.

Five micrograms of endometrial RNA was separated on a $1.5 \%$ agarose gel containing $\times 1$ Mops buffer and $12.5 \%(\mathrm{v} / \mathrm{v})$ formaldehyde under standard conditions. After separation, the gels were vacublotted onto Hybond-N nylon membrane (Amersham International) using $\times 20$ saline-sodium citrate buffer (Sigma Poole, Dorset). The RNA was fixed by ultraviolet crosslinkage and hybridized at $42^{\circ} \mathrm{C}$ overnight with 
Table 1. The primer set sequences used for the reverse transcription-polymerase chain reaction of mRNA encoding for the progesterone receptor

\begin{tabular}{|c|c|c|c|}
\hline $\begin{array}{l}\text { Primer } \\
\text { set }\end{array}$ & Nucleotides & Sequence $\left(5^{\prime}\right.$ to $\left.3^{\prime}\right)$ & $\begin{array}{l}\text { Size of } \\
\text { product }\end{array}$ \\
\hline 1 & $2192-2779$ & $\begin{array}{l}\text { GTGGTCTAAATCATTGCCAGGTTTTCG } \\
\text { GCTTCAAGTTAGCCAAGAAGA }\end{array}$ & 587 \\
\hline 2 & $2192-2607$ & $\begin{array}{l}\text { GTGGTCTAAATCATTGCCAGGTTTTCG } \\
\text { ACGATGTGAGCTCGACACAACTC }\end{array}$ & 415 \\
\hline 3 & $2584-2779$ & $\begin{array}{l}\text { GAGTTGTGTCGAGCTCACAGCG } \\
\text { GTTTCACCATCCCTGCCAAT }\end{array}$ & 195 \\
\hline 4 & $2429-2607$ & $\begin{array}{l}\text { GCTTCAAGTTAGCCAAGAAGA } \\
\text { ACGATGTGAGCTCGACACAACTC }\end{array}$ & 178 \\
\hline
\end{tabular}

$\left[\alpha-{ }^{32} \mathrm{P}\right] \mathrm{dCTP}$-labelled DNA probes. A 1.2 kilobase $\left[\alpha-{ }^{32} \mathrm{P}\right] \mathrm{dCTP}-$ labelled probe for mRNA encoding for the progesterone receptor was prepared from a human progesterone receptor complementary DNA clone, hPRI (kindly provided by P. Chambon, Strasbourg). The membranes were washed at high stringency $(\times 0.1$ saline-sodium citrate buffer containing $0.1 \%$ SDS (Sigma)) for $15 \mathrm{~min}$ at $65^{\circ} \mathrm{C}$ and then autoradiography was carried out at $-70^{\circ} \mathrm{C}$ for $24-48 \mathrm{~h}$. Before probing for $\beta$-actin the progesterone receptor probe was removed from the membrane by incubating the membrane in $0.4 \mathrm{~mol}$ sodium hydroxide $1^{-1}$ at $42^{\circ} \mathrm{C}$ for $30 \mathrm{~min}$ followed by washing the membrane in $0.2 \mathrm{~mol}$ Tris- $\mathrm{HCl}$ buffer $\mathrm{l}^{-1}$ at $\mathrm{pH} 7.5$ containing $\times 0.1$ saline-sodium citrate buffer and $0.1 \%$ SDS for $15 \mathrm{~min}$. The hybridization-transfer membrane was reprobed with a $\beta$-actin cDNA fragment to examine the quantity of mRNA present. Band densities for the mRNA encoding for the progesterone receptor and mRNA encoding $\beta$-actin were visually compared between the different phases of the menstrual cycle.

\section{Statistical analyses}

Data were analysed by one-way analysis of variance using the STATGRAPHICS program (version 5) on an IBM PC. Results are expressed as means \pm SEM.

\section{Results}

\section{Dating of the menstrual cycle}

Examination of the haematoxylin-eosin stained endometrial samples under a light microscope confirmed the phase of the menstrual cycle as identified by the last menstrual period. No pathological abnormalities were observed in the samples used in this study. The endocrine profiles obtained from the serum of the women at the time of surgery confirmed the phase of the menstrual cycle. Mean progesterone concentrations during the early proliferative, late proliferative, early secretory and late secretory phases were $2.17 \pm 1.20,3.08 \pm 2.81,21.00 \pm 15.40$

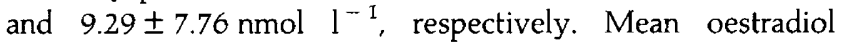
concentrations during the same menstrual cycle phases were $345.0 \pm 222.7, \quad 388.0 \pm 291.7, \quad 264.2 \pm 139.5$ and $194.5 \pm 112.7 \mathrm{pmol} \mathrm{l}^{-1}$, respectively.

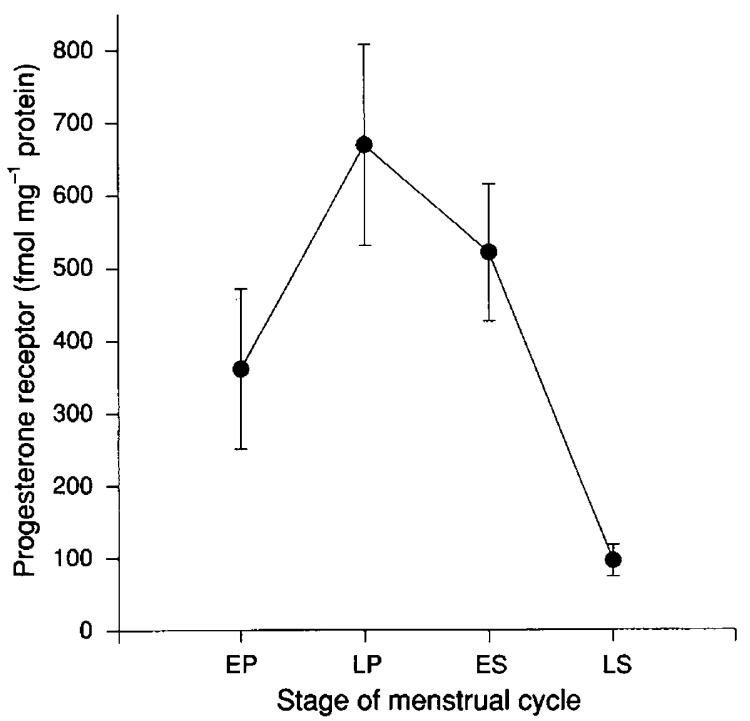

Fig. 1. Concentrations of endometrial progesterone receptor during the human menstrual cycle. The menstrual cycle was divided into four stages: early proliferative (EP): days 6-9; late proliferative (LP): days 10-14; early secretory (ES): days 15-21 and late secretory (LS) days $22-28$. The results are expressed as means \pm SEM.

\section{Concentrations of progesterone receptor protein}

The mean values for the cytosolic concentrations of progesterone receptor protein in the endometrium during the menstrual cycle are shown (Fig. 1). The progesterone receptor concentrations were found to be maximal during the late proliferative phase and minimal during the late secretory phase of the cycle. Within each phase of the cycle, there were large individual variations in the concentrations of progesterone receptors but significant differences were observed between all phases of the menstrual cycle $(P<0.003)$.

Quantification of $m R N A$ encoding for the progesterone receptor by $R T-P C R$

Initially, several primer sets were used to amplify progesterone receptor cDNA and, in each case, a product of the expected size was generated (Fig. 2). Primer set 3 was used in 


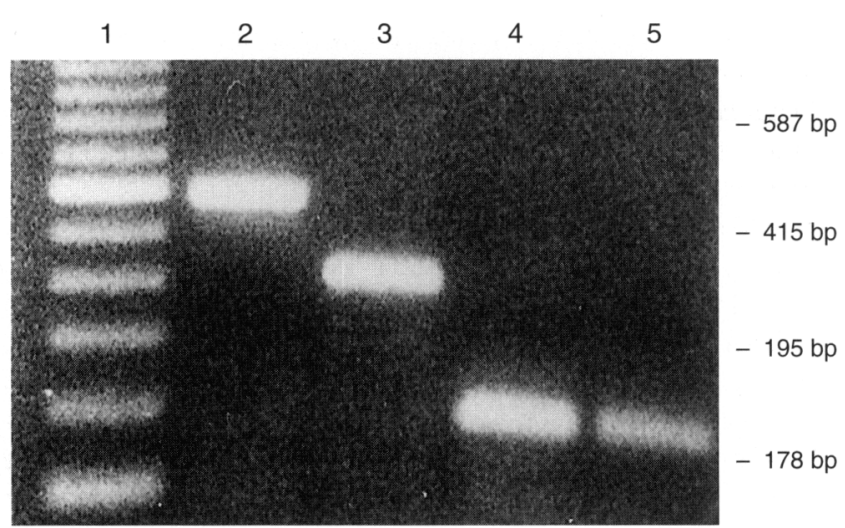

Fig. 2. Products from the reverse-transcription polymerase chain reaction generated from human endometrial cDNA using four different primer sets for mRNA encoding for the progesterone receptor. (Details of the primer sets are given in Table 1.) Lane 1 : $100 \mathrm{bp}$ molecular mass ladder; lane 2: product of $587 \mathrm{bp}$, generated using primer set 1; lane 3: product of $415 \mathrm{bp}$, generated using primer set 3; lane 4: product of $195 \mathrm{bp}$ generated using primer set 3 and lane 5: product of $178 \mathrm{bp}$ generated using primer set 5 .

1

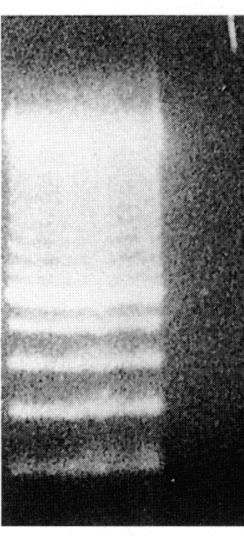

2

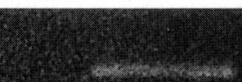

Fig. 3. A 195 bp product from the reverse-transcription polymerase chain reaction was generated using primer set 3 from first strand cDNA prepared from human endometrial cells and a product of greater than $2000 \mathrm{bp}$ was generated under the same conditions using genomic DNA. Lane I: 100 bp molecular mass ladder; lane 2: reagent negative control (no cDNA or DNA); lane 3: genomic DNA and lane 4: endometrial cDNA.

subsequent analyses since the product was easily separated from the $\beta$-actin product and the set worked well under the multiplex PCR conditions. The intron-exon structure is not known but on the basis of the intron-exon structure of the chicken progesterone receptor, this primer set was expected to cross an intron (Huckaby et al., 1987). This was confirmed for the human progesterone receptor gene, as a $195 \mathrm{bp}$ product was generated using primer set three with the cDNA, but not with genomic DNA. However, a product of $2-3 \mathrm{~kb}$ was generated using genomic DNA suggesting that introns in the human gene are of a similar size to the chicken (Fig. 3). As products of $195 \mathrm{bp}$ were generated only with the first strand cDNA and not with the genomic DNA, the possibility that the products generated from the endometrial $\mathrm{CDNA}$ were derived

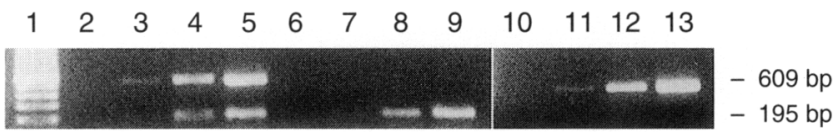

Fig. 4. The exponential increase in product from the reversetranscription polymerase chain reaction with increasing cycle number. Aliquots of the PCR reaction were taken after 20,25, 30 and 35 cycles. A product of $609 \mathrm{bp}$ was generated from the $\beta$-actin primer set after 20 cycles (lane 10), 25 cycles (lane 11), 30 cycles (lane 12), and 35 cycles (lane 13). A product of $195 \mathrm{bp}$ was generated from the primer set for mRNA encoding for the progesterone receptor after 20 cycles (lane 6), 25 cycles (lane 7), 30 cycles (lane 8) and 35 cycles (lane 9). Both products were generated when primer sets for mRNAs coding for the progesterone receptor and $\beta$-actin were used in the same reaction (lanes 2-5) for 20 (lane 2), 25 (lane 3), 30 (lane 4) and 35 (lane 5) cycles. Lane 1 shows the $100 \mathrm{bp}$ molecular mass ladder.

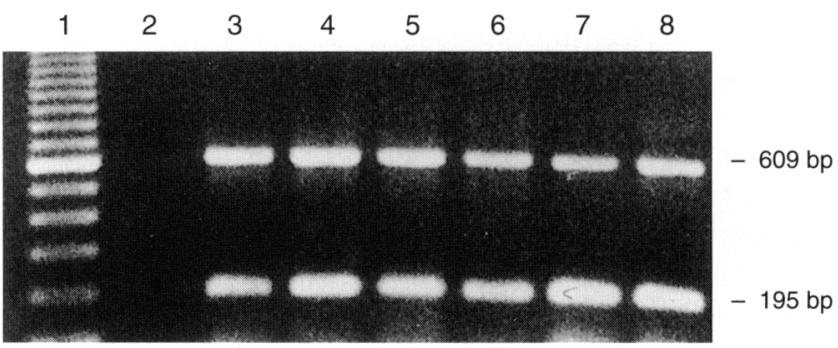

Fig. 5. A 609 bp product from the reverse-transcription polymerase chain reaction was generated using primers for mRNA encoding for $\beta$-actin and a $195 \mathrm{bp}$ product was generated with the progesterone receptor primer set three from cDNA prepared from breast cancer cells and endometrial cells. Lane 1: $100 \mathrm{bp}$ molecular mass ladder; lane 2: reagent negative control (no cDNA); lane 3 : MCF-7 breast cancer cell line; lane 4: T47-D breast cancer cell line; lanes 5-8: endometrium from different stages of the menstrual cycle.

from genomic DNA was eliminated. Time course studies revealed that the amplification of the PCR reaction was within the exponential phase at 30 cycles (Fig. 4).

mRNA encoding for the progesterone receptor and $\beta$-actin was successfully detected in all endometrial samples by RT-PCR, examples of which are shown (Fig. 5). No significant differences were found between the different stages of the menstrual cycle (Fig. 6). In cases in which sufficient RNA was available, conventional northern blots were performed using the progesterone receptor $\mathrm{CDNA}$ probe and $\beta$-actin cDNA probes as independent means of verifying the RT-PCR results. In each case, the results of northern blotting were consistent with those obtained by RT-PCR.

\section{Discussion}

The changes in the concentration of endometrial progesterone receptor protein observed throughout the menstrual cycle in the study reported here are in agreement with previous observations (Bayard et al., 1978; Levy et al., 1980; Bergqvist and Ferno, 1993). In the present study, an assay based on the direct antigenic recognition of the progesterone receptor molecules by specific monoclonal antibodies was used to quantify the progesterone receptor throughout the menstrual 


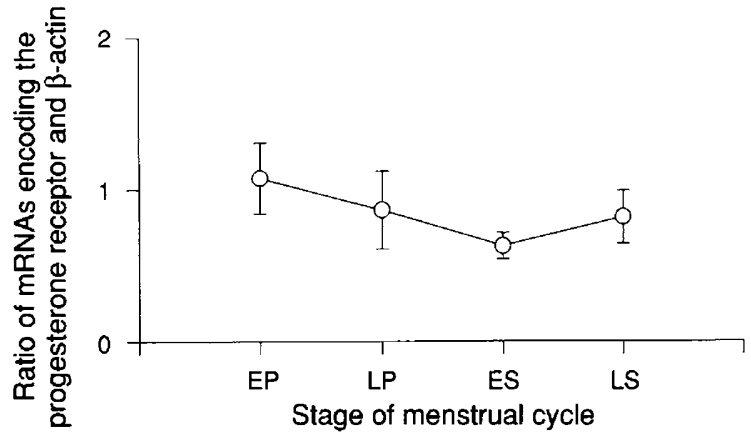

Fig. 6. The ratios of mRNAs encoding the progesterone receptor and $\beta$-actin during the menstrual cycle. The menstrual cycle was divided into four stages: early proliferative $(E P)$ : days 6-9; late proliferative (LP): days 10-14; early secretory (ES): days 15-21 and late secretory (LS): days 22-28. Identical results were obtained by the reverse transcription-polymerase chain reaction and northern blotting. Results are expressed as means \pm SEM. There were no significant differences between the stages of the menstrual cycle.

cycle. This method has the advantage of being independent of steroid-binding activity and also recognizes the $120 \mathrm{kDa}$ and $95 \mathrm{kDa}$ molecular mass forms of the human progesterone receptor. In agreement with previous studies using this method, the concentration of progesterone receptors was found to increase during the proliferative phase and reach a maximum in the late proliferative phase, and then to fall to low concentrations by the late secretory phase (Bergqvist and Ferno, 1993). Similar results were also observed in studies using steroid-binding methods that measure the endometrial cytosolic, nuclear and total progesterone concentrations (Bayard et al., 1978; Levy et al., 1980). In addition, immunocytochemical analysis of the progesterone receptor using monoclonal antibodies have shown similar variations throughout the menstrual cycle (Garcia et al., 1988). In the present study the concentration of cytosolic progesterone receptors throughout the menstrual cycle was determined but no attempt was made to determine the concentration of receptors tightly bound to nuclei. Immunocytochemical studies have found that nuclear staining for progesterone receptors correlates well with cytosolic concentrations of progesterone receptors as determined by steroid-binding assays (Perrot-Applanat et al., 1987).

The use of RT-PCR to quantify mRNA concentrations in tissues is controversial because of difficulties in ensuring efficient cDNA synthesis and amplification, as well as accurately correcting for inter-reaction variation. In the study described here, care was taken to preserve the integrity of the mRNA during cDNA synthesis and to ensure the analysis of the PCR products was made during the exponential phase of PCR amplification. The amplification of both progesterone receptor and $\beta$-actin RT-PCR products was in the exponential phase at 30 cycles when analysed separately or in the same RT-PCR reaction. Similar amounts of RT-PCR product were generated when the reaction was conducted with the primer sets individually or in combination. $\beta$-Actin was used in the PCR reactions to correct for variation between reactions in amplification efficiency. Studies in vitro on the rat uterus have questioned the use of $\beta$-actin as a suitable control in endocrine studies as oestradiol treatment significartly increases the amount of mRNA encoding for $\beta$-actin (Rosser et al., 1993). Detailed analysis of the different actin isoforms in immature rat uteri revealed only a 1.4-fold increase in $\beta$-actin ( $\mathrm{Hsu}$ and Frankel, 1987). Although no data from studies in vivo are available for the human menstrual cycle, the alterations in mRNA encoding for $\beta$-actin observed in vitro in rats are too small to alter qualitatively the results presented here.

There have been no previous studies in which the progesterone receptor protein and mRNA encoding for the progesterone receptor have been measured simultaneously throughout the menstrual cycle. Although large differences were observed in the concentration of progesterone receptors during the menstrual cycle, no significant change was seen in the content of mRNA encoding for the progesterone receptor in the endometrium. As the mRNA encoding for the progesterone receptor was analysed by both RT-PCR and by northern blotting, it seems unlikely that this finding can be ascribed solely to the techniques used. A similar dissociation in the content of mRNA encoding the progesterone receptor and concentrations of the progesterone receptor has been observed in a small study in uterine leiomyomas (Brandon et al., 1993). The leiomyomas were found to have higher amounts of mRNA encoding for the progesterone receptor than did adjacent myometrium when analysed by RT-PCR or northern analysis, but no correlation was observed between the amount of mRNA and the phase of the menstrual cycle in the leiomyomas. An amplified progestin signal may play a role in the abnormal biology of these tumours and may act at a posttransitional site (Brandon et al., 1993).

In breast cancer cell lines, studies investigating the regulation of the progesterone receptor have shown a close relationship between the changes in the content of mRNA encoding for the progesterone receptor and the amount of progesterone receptor in cells in response to a variety of ligands. Consequently, the changes in the progesterone receptor content of these cells appear to be accounted for by changes at the transcriptional level (Read et al., 1988). Other studies on breast cancer cell lines have failed to show a correlation between the amount of mRNA encoding for the progesterone receptor and concentrations of progesterone receptor (Vegeto et al., 1990) which suggests that there are other mechanisms involved in controlling the numerous steps in the synthesis of progesterone receptors.

Multiple human mRNAs encoding for the progesterone receptor have been found in breast cancer cell lines and in human endometrium. Six mRNA bands are observed by northern blot hybridization experiments in breast and endometrial tissues with molecular masses between $11.4 \mathrm{~kb}$ and $2.5 \mathrm{~kb}$ (Misrahi et al., 1987). The progesterone receptor is believed to be encoded by a single copy gene and it has been proposed that the supernumerary progesterone receptor messages may arise by alternate exon splicing, by differences in the 5 '-untranslated regions or by variable 3 '-extensions arising from alternative polyadenylation sites (Jeltsch $e t$ al., 1986). In our study, the relative quantities of the different mRNA species encoding for the progesterone receptor were not determined. It is possible that during the menstrual cycle, alterations in the relative amounts of these mRNA species are observed and that these alterations could account for the variation in 
concentration of progesterone receptor protein seen throughout the cycle.

In conclusion, there appears to be a dissociation between the amounts of mRNA encoding the progesterone receptor and the progesterone receptor protein in the endometrium during the menstrual cycle. At present the mechanism by which the progesterone receptor is controlled is unclear. In other tissues, the control of the amount and activity of steroid receptors appears to involve a combination of translational and posttranslational events. It may be that this is also the case for the endometrium, as control at the translational or transcriptional levels alone would be too simplistic for such a dynamic tissue undergoing cyclical proliferation and differentiation.

The expert technical assistance of P. Englefield, C. Sieniawska and C. Glen is gratefully acknowledged. The financial support of the Wellcome Trust is gratefully acknowledged.

\section{References}

Bayard F, Damilano S, Robel P and Baulieu E-E (1978) Cytoplasmic and nuclear estradiol and progesterone receptors in human endometrium journal of Clinical Endocrinology and Metabolism 46 635-648

Bergqvist $A$ and Ferno $M$ (1993) Oestrogen and progesterone receptors in endometriotic tissue and endometrium: comparison of different cycle phases and ages Human Reproduction 8 2211-2217

Bradford MM (1976) A rapid and sensitive method for the quantitation of microgram quantities of protein utilizing the principle of protein-dye binding Analytical Biochemistry 72 248-254

Brandon DD, Bethea CL, Strawn EY, Keenan EJ and Clinton GM (1993) Progesterone receptor messenger ribonucleic acid (mRNA) and protein are over expressed in human uterine leiomyomas Clinical Research 41107

Ferenczy A, Bertrand G and Gelfand MM (1979) Proliferation kinetics of human endometrium during the normal menstrual cycle American journal of Obstetrics and Gynecology 133 859-867

Garcia E, Bouchard P, De Brux J, Berdah J, Frydman R, Schaison G, Milgrom E and Perrot-Applanat M (1988) Use of immunocytochemistry of progesterone and estrogen receptors for endometrial dating Journal of Clinical Endocrinology and Metabolism $67 \quad 80-87$

Healy DL and Hodgen GD (1983) The endocrinology of human endometrium Obstetrical and Gynecological Survey 38 509-530

Horwitz KB, Zava DT, Thialagar AK, Jensen EM and McGuire WL (1978) Steroid receptor analyses of nine human breast cancer cell lines Cancer Research 38 2434-2437
Hsu C-Y] and Frankel FR (1987) Effect of estrogen on the expression of mRNAs of different actin isoforms in immature rat uterus Journal of Biological Chemistry $2629594-9600$

Huckaby CS, Conneely OM, Beattie WG, Dobson ADW, Tsai M-J and O'Malley BW (1987) Structure of the chromosomal chicken progesterone receptor gene Proceedings of the National Academy of Sciences USA 84 8380-8384

Jeltsch JM, Krozowski Z, Quirin-Stricker C, Gronmeyer H, Simpson RJ, Garnier JM, Krust A and Jacob F (1986) Cloning of the chicken progesterone receptor Proceedings of the National Academy of Sciences USA 83 5424-5428

Katzenellenbogen BS (1980) Dynamics of steroid hormone receptor Annual Review of Physiology 42 17-35

Kreitmann B, Bugat R and Bayard F (1979) Estrogen and progestin regulation of the progesterone receptor concentration in human endometrium Journal of Clinical Endocrinology and Metabolism 49 926-929

Levy C, Robel P, Gautray JP, De Brux J, Verma U, Descomps B, Baulieu EE and Eycheene $E$ (1980) Estradiol and progesterone receptors in human endometrium: normal and abnormal menstrual cycles and early pregnancy American Journal of Obstetrics and Gynecology 136 646-65I

Misrahi M, Atger M, d'Auriol L, Loosfely H, Meriel C, Fridlansky F, GuiochonMantel A and Galibert F (1987) Complete amino acid sequence of the human progesterone receptor deduced from cloned cDNA Biochemical and Biophysical Research Communications 143 740-748

Noyes RW, Hertig AT and Rock J (1950) Dating the endometrial biopsy Fertility and Sterility $13-25$

Perrot-Applanat M, Groyer-Picard MT, Lorenzo F, Jolivet A, Hai MTV, Pallud C, Spyratos F and Milgrom E (1987) Immunocytochemical study with monoclonal antibodies to progesterone receptor in human breast tumors Cancer Research 47 2652-2661

Ponte P, Ng SY, Gunning P and Kedes L (1984) Evolutionary conservation in the untranslated regions of actin mRNAs: DNA sequence of a human beta-actin cDNA Nucleic Acids Research 12 1687-1696

Read LD, Snider CE, Miller IS, Greene GL and Katzenellenbogen BS (1988) Ligand-modulated regulation of progesterone receptor messenger ribonucleic acid and protein in human breast cancer cell lines Molecular Endocrinology 2 263-271

Rosser M, Chorich L, Howard E, Zamorano P and Mahesh VB (1993) Changes in rat uterine estrogen receptor messenger ribonucleic acid levels during estrogen- and progesterone-induced estrogen receptor depletion and subsequent replenishment Biology of Reproduction 48 89-98

Sumida C, Lecerf F and Pasqualini JR (1988) Control of progesterone receptors in fetal uterine cells in culture: effects of estradiol, progestins, antiestrogens, and growth factors Endocrinology 122 3-11

Vegeto E, Cocciolo MG, Raspagliesi F, Piffanelli A, Fontanelli R and Maggi A (1990) Regulation of progesterone receptor gene expression Cancer Research $505291-5295$

Yussman MA, Taylor ML, Miyata J and Pheteplace C (1970) Serum levels of follicle-stimulating hormone, luteinising hormone, and plasma progestins correlated with human ovulation Fertility and Sterility 21 117-125 